\title{
Correction to: Acute and chronic diabetes complications associated with self-reported oral health: a retrospective cohort study
}

Kamini Kaura Parbhakar ${ }^{* *}$, Laura C. Rosella ${ }^{2,3}$, Sonica Singhal ${ }^{1,4}$ and Carlos R. Quiñonez ${ }^{1,2,3}$

\section{Correction to BMC Oral Health (2020) 20:66 https:// doi.org/10.1186/s12903-020-1054-4}

Following publication of the original article [1], the authors identified an error in the Competing interests section: "Carlos Quiñonez receives consulting income for dental care related issues from Green Shield Canada" should be added.

The original article has been updated.

\section{Author details}

${ }^{1}$ Dental Public Health, Faculty of Dentistry, University of Toronto, Toronto, Ontario, Canada. ${ }^{2}$ Division of Epidemiology, Dalla Lana School of Public Health, University of Toronto, Toronto, Ontario, Canada. ${ }^{3}$ Institute for Clinical Evaluative Sciences, Toronto, Ontario, Canada. ${ }^{4}$ Public Health Ontario Toronto, Ontario, Canada.

Published online: 12 April 2021

\section{Reference}

1. Parbhakar KK, Rosella LC, Singhal S, Quiñonez CR. Acute and chronic diabetes complications associated with self-reported oral health: a retrospective cohort study. BMC Oral Health. 2020;20:66. https://doi.org/ 10.1186/s12903-020-1054-4

\section{Publisher's Note}

Springer Nature remains neutral with regard to jurisdictional claims in published maps and institutional affiliations.

Full list of author information is available at the end of the article

(C) The Author(s) 2021. Open Access This article is licensed under a Creative Commons Attribution 4.0 International License, which permits use, sharing, adaptation, distribution and reproduction in any medium or format, as long as you give appropriate credit to the original author(s) and the source, provide a link to the Creative Commons licence, and indicate if changes were made. The images or other third party material in this article are included in the article's Creative Commons licence, unless indicated otherwise in a credit line to the material. If material is not included in the article's Creative Commons licence and your intended use is not permitted by statutory regulation or exceeds the permitted use, you will need to obtain permission directly from the copyright holder. To view a copy of this licence, visit http://creativecommons.org/licenses/by/4.0/. The Creative Commons Public Domain Dedication waiver (http://creativeco mmons.org/publicdomain/zero/1.0/) applies to the data made available in this article, unless otherwise stated in a credit line to the data. 